\title{
Sensitivity index of flood and tidal flood in Pekalongan City and Regency
}

\author{
Halimatus Sa'diyah", Imam Buchori, Amirudin \\ Environmental Sciences, Postgraduate School, Diponegoro University, Semarang-Indonesia
}

\begin{abstract}
Pekalongan is located in the northern coastal lowland of Java. The conditions are driving the region into areas that are vulnerable to climate change- the flood and tidal flood. Sensitivity represents a region's sensitivity level to certain catastrophic events including the flood and tidal flood. The study uses the sensitivity index method. The data are obtained from various sources in the form of primary and secondary data. The sensitivity index is classified into five classes (very high, high, middle, low, and very low). The purpose of this study is to know the sensitivity index in Pekalongan city and the Pekalongan regency. The research shows that the sensitivity index in Pekalongan fell into a middle category. The spatial index of sensitivity is in the middle category due to a sensitivity index is dominated by a middle category at $59 \%$ percentage rate.
\end{abstract}

Keywords: Sensitivity Index, Flood and Tidal Flood, Pekalongan.

\section{Introduction}

Pekalongan City is one of the northern regions of Java Island which is currently facing a flood and tidal flood [1]. Pekalongan City is included in an area vulnerable to the effects of climate change, especially in the form of floods and tidal floods known as rob [2] . Based on the RAN API, the City of Pekalongan is included in areas that are vulnerable to climate change, one of which is tidal flooding with a total inundation area of 1,920 hectares. Some villages in the North and East Pekalongan Subdistricts were inundated by tidal flooding with a flood area of 1,249.42 ha [2]. Flood disaster in the City and Pekalongan Regency is a phenomenon that occurs every year. Floods that occur in this region are affected by land subsidence which forms new basins in areas with flat topography, poor drainage management, forest land conversion in upstream areas, and high rainfall factors during the rainy season [3]. Complex land use in coastal areas will also make coastal areas vulnerable to the effects of rising sea levels [4].

Sensitivity is an internal condition of a system that is determined by humans and their environmental conditions. The human condition is social aspects such as rights, institutions, economic structures, and so on. Environmental conditions comprise natural or biophysical

\footnotetext{
*Corresponding author: halimatussadiyah@students.undip.ac.id
} 
conditions, such as soil, water, climate, mineral, and ecosystem structure and function [5]. The sensitivity of a system to climate change reflects "the extent to which a system is affected", either adversely or profitably, by variability or climate change. The effect may be direct (eg changes in crop yields in response to changes in mean, range, or temperature variability) or indirect (eg damage caused by an increase in the frequency of coastal flooding due to sea-level rise) [5]. Sensitivity reflects the responsiveness of a system to the effects of climate, and the level of climate change that can influence it in its current form. Thus, sensitive systems become very responsive to climate and can be significantly affected by small climate changes.

This writing aims to determine the spatial sensitivity index of floods and tidal flooding in Pekalongan City and the Pekalongan Regency.

\section{Method}

This study uses data collection, processing, and analysis methods for the preparation of sensitivity indexes. The Sensitivity Index (S) is arranged based on 10 components $(\mathrm{K} 1, \ldots$, $\mathrm{K} 10)$ where each component is formed from the indicators compiled which are selected to represent the sensitivity index in the City / Regency of Pekalongan. Data on components and indicators are obtained from various sources in the form of primary and secondary data. The study was conducted by collecting primary data taken by direct observation and interview (in-depth interviews) [6,7]. Primary data in the form of statistical data obtained from each city and district government and from the village office in the study area. Primary data were obtained through questionnaire surveys and direct observations in the field.

\section{Result and discussion}

\subsection{Components of the sensitivity index}

Sensitivity is the rate at which a system can be affected, either negatively or positively, by pressure stimuli or climate-related disturbances $[5,8]$. Sensitivity consists of two parts, a condition of community sensitivity which includes social capital such as population, economic structure, to the existing institutions in the community, and environmental sensitivity conditions that include water, soil, weather conditions [8]. The Sensitivity Index (S) is arranged based on 10 components $(\mathrm{K} 1, \ldots, \mathrm{K} 10)$ where each component is formed from the indicators compiled which are selected to represent the sensitivity index in the City / Regency of Pekalongan. Each component used to determine the sensitivity index has scientific considerations resulting from a literature review and scientific discussion forums in the form of FGD (Focus Group Discussion). The sensitivity index value is obtained from the sum of the values of all components used by the weight given to each of these components. Then normalization of the sensitivity index data is performed so that each data used has a range from zero to one (0-1).

The results of the sensitivity index modeling are classified into 5 classes (very high, high, middle, low, and very low). Classification is done by proportionally dividing the sensitivity value (0-1) into 5 Classes. The sensitivity level is in the high category if the sensitivity index is above 0.8 to 1 , and in the very low category if the sensitivity index is 
below 0.2 to 0 . The components and indicators that make up the spatial model of the sensitivity index shown in Table 1.

Table 1. Components of Sensitivity Index

\begin{tabular}{|c|c|}
\hline Component & Indicator \\
\hline $\begin{array}{l}\text { Infrastructure and } \\
\text { Infrastructure and } \\
\text { settlements (K1) } \\
\text { settlements (K1) }\end{array}$ & $\begin{array}{l}\text { - Percent of non-permanent buildings from the total building } \\
\text { (Percentage of houses that are not strong enough to withstand } \\
\text { (Percentage of houses that are not strong enough to withstand } \\
\text { disasters per village). } \\
\text { disasters per village). } \\
\text { - Percentage of green area per village (\%). }\end{array}$ \\
\hline Poverty (K3) & - The ratio of the poor population \\
\hline $\begin{array}{l}\text { Vulnerable Groups } \\
\text { (K4) }\end{array}$ & $\begin{array}{l}\text { The ratio of the female population (Gender) } \\
\text { - The ratio of the elderly population ( }>60 \text { years) } \\
\text { - The ratio of children }(<12 \text { years) } \\
\text { - The ratio of the number of people with disabilities }\end{array}$ \\
\hline $\begin{array}{l}\text { Per capita income }(\mathrm{K} 5) \\
\text { Per capita income } \\
(\mathrm{K} 5)\end{array}$ & $\begin{array}{l}\text { - Percentage of RTs whose members are farming, aquaculture, or } \\
\text { fishermen to the total livelihood per village (\%). } \\
\text { fishermen to the total livelihood per village }(\%) \text {. }\end{array}$ \\
\hline $\begin{array}{l}\text { Land Ownership (K6) } \\
\text { Land Ownership (K6) }\end{array}$ & $\begin{array}{l}\text { - Percentage of RT that do not have legality (ownership) of land } \\
\text { per village }(\%) \\
\text { per village }(\%)\end{array}$ \\
\hline Health (K7) & The number of incidence of water-borne diseases per district. \\
\hline Critical Assets (K8) & $\begin{array}{l}\text { Number of critical asset facilities / important assets } \\
\text { damaged/affected by floods and rob (health, infrastructure, } \\
\text { markets, energy, transportation, etc.) }\end{array}$ \\
\hline $\begin{array}{l}\text { Impacted GRDP (K9) } \\
\text { Impacted GRDP (K9) }\end{array}$ & $\begin{array}{l}\text { - Percentage of GRDP contribution per affected sector } \\
\text { (aquaculture and paddy farming) per sub-district. } \\
\text { (aquaculture and paddy farming) per sub-district. }\end{array}$ \\
\hline $\begin{array}{l}\text { Infrastructure, } \\
\text { facilities, and utilities } \\
\text { (K10) }\end{array}$ & - Road classes (transportation) that are often affected. \\
\hline
\end{tabular}




\subsection{Sensitivity index}

The spatial study area covers 84 villages, consisting of 26 villages in Pekalongan City and 58 villages in the Pekalongan Regency. The results of composite sensitivity index indicators and sensitivity components show complex sensitivity indices ranging from very high, high, middle, low, and very low. Areas that are villages with very high index categories are only found in Pekalongan Regency and not found in Pekalongan City. The distribution of sensitivity indexes in the medium category is dominantly dominant in the city of Pekalongan, and only 5 sensitivity indexes are found in the high category in this region, Bandengan, Jenggot, Kalibaros, Poncol and Sokoduwet village. A very high sensitivity index is generally spread in the coastal areas of the Pekalongan Regency. A very high sensitivity index was only found in 2 villages in the middle area of the Kupang watershed, Salakbrojo Village, Kedungwuni District and Kedungkebo Village, Karangdadap District, Pekalongan Regency.

The coastal area which consists of villages that are directly adjacent to the coast has a sensitivity index variation ranging from very high, high, and medium. This coastal area is dominated by a very high level of sensitivity consisting of 5 villages, medium sensitivity 6 villages, and high sensitivity 2 villages. The coastal area which consists of villages that are directly adjacent to the coast has a sensitivity index variation ranging from very high, high, and medium. This coastal area is dominated by a very high level of sensitivity consisting of 5 villages, medium sensitivity 6 villages, and high sensitivity 2 villages. For more details, the results of the sensitivity level per village in the city and regency of Pekalongan shown in Table 2.

Table 2. The sensitivity level of Pekalongan city and regency

\begin{tabular}{|c|c|c|c|c|}
\hline Very High & High & Middle & Low & Very Low \\
\hline $\begin{array}{l}\text { - Salakbrojo } \\
\text { - } \\
\text { Kedungkebo } \\
\text { - Api-api } \\
\text { - Semut } \\
\text { - Tratebang } \\
\text { - Jeruksari } \\
\text { - Mulyorejo }\end{array}$ & $\begin{array}{l}\text { - Bandengan } \\
\text { - Poncol } \\
\text { - Kalibaros } \\
\text { - Sokoduwet } \\
\text { - Jenggot } \\
\text { - Batursari } \\
\text { - Jolotigo } \\
\text { - Kalirejo } \\
\text { - Karangasem } \\
\text { - Talun } \\
\text { - Kayupuring } \\
\text { - Tlogohendro } \\
\text { - Jrebeng kembang } \\
\text { - Kalilembu } \\
\text { - } \\
\text { Kebonrowopucang } \\
\text { - Logandeng }\end{array}$ & $\begin{array}{l}\text { - Krapyak } \\
\text { - Panjang Baru } \\
\text { - Degayu } \\
\text { - Kandang } \\
\text { Panjang } \\
\text { - Panjang Wetan } \\
\text { - Gamer } \\
\text { - Kauman } \\
\text { - Noyontaansari } \\
\text { - Kuripan } \\
\text { Yosorejo } \\
\text { - Buaran } \\
\text { Kadranan } \\
\text { - Kuripan } \\
\text { Kertoharjo } \\
\text { - Bendan Kergon } \\
\text { - Medono } \\
\\
\text { - Podosugih } \\
\text { - Tirto }\end{array}$ & $\begin{array}{l}\text { - Padukuhan } \\
\text { Keraton } \\
\text { - Donowangun } \\
\text { - Kebonsari }\end{array}$ & $\begin{array}{l}\text { - Klogo } \\
\text { - Sapuro } \\
\text { Kebulen } \\
\text { - Pringrejo }\end{array}$ \\
\hline
\end{tabular}




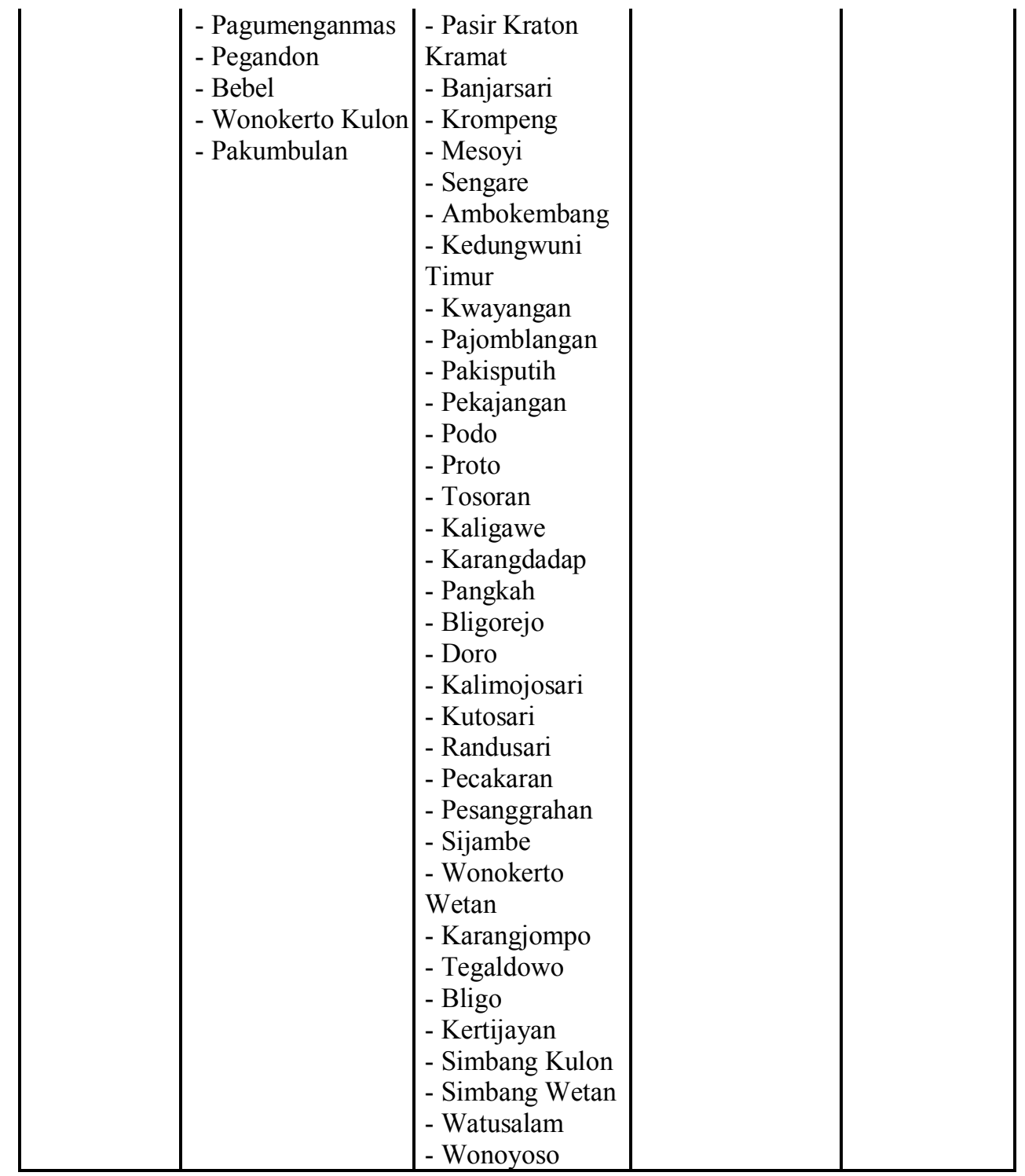

The upstream area of the Kupang watershed is dominated by a high level of sensitivity consisting of 2 villages, namely Kedungkebo Village, Karangdadap District and Salakbrojo Village, Kedungwuni District. The middle area of the Kupang watershed is dominated by complex sensitivity levels too, ranging from very high, high, medium, low, and very low. The distribution of villages with medium and high vulnerability index dominates the middle area of this watershed.

The sensitivity index is dominated by the middle category with a percentage value of $59 \%$, then followed by the sensitivity index with a high category with a percentage of $25 \%$. The sensitivity index with a very high category was found only $8 \%$ of the total number of villages studied. Based on the percentage of the dominant sensitivity level found, it can be stated that the sensitivity index in this region is in the middle to high range. 


\section{Conclusion}

The dominant sensitivity level found in Pekalongan city and Pekalongan district can be stated that the sensitivity index in this region is in the medium range, with the sensitivity index being dominated by the medium category with a percentage of $59 \%$ and then followed by the sensitivity index with a high category with a percentage of $25 \%$.

\section{References}

[1] A. S. Drestanto, A. Indarjo, and M. Helmi, "Pemetaan Area Genangan Banjir Pasang Di Kawasan Lahan Budidaya Air Payau Kota Pekalongan Provinsi Jawa Tengah,” J. Mar. Res., vol. 3, no. 4, pp. 439-446, (2014)

[2] Bappeda, "Rancangan RKPD Kota Pekalongan Tahun 2019," no. April 2018, (2019)

[3] A. Ismanto, A. Wirasatriya, M. Helmi, A. Hartoko, and P. Prayogi, "Model Sebaran Penurunan Tanah di Wilayah Pesisir Semarang," Ilmu Kelaut., vol. 14, no. 4, pp. 189-196, (2009)

[4] W. S. Utami, P. Subardjo, and M. Helmi, "Studi Perubahan Garis Pantai Akibat Kenaikan Muka Air Laut Di Kecamatan Sayung, Kabupaten Demak," J. Oceanogr., vol. 6, no. 1, pp. 281-287, (2017)

[5] IPCC, "Climate change 2007: impacts, adaptation and vulnerability," no. 2300, (2007)

[6] B. W. Hastanti and P. Purwanto, “Analisis Keterpaparan, Sensitivitas, dan Kapasitas Adaptasi Masyarakat Terhadap Kekeringan di Dusun Pamor, Kradenan, Grobogan (Analysis of Exposure, Sensitivity and Community Adaptation Capacity to Drought in Pamor Hamlet, Kradenan, Grobogan)," J. Chem. Inf. Model., vol. 53, no. 9, pp. 1689-1699, (2019)

[7] BAPPENAS, "Modul-modul Pengarus-utamaan Perubahan Iklim dalam Perencanaan Pembangunan Daerah Juni 2016," (2016)

[8] R. Robianto and M. Massudin, "Kerentanan Kawasan Permukiman Rawan Banjir Kampung Kolam Kelurahan Tanjungpinang Barat, Tanjungpinang," J. Rekayasa Sipil, vol. 16, no. 1, pp. 25-37, (2020) 